The Bangladesh Veterinarian (2012) 29(1) : 7 - 16

\title{
Effects of concentrate supplementation on growth, reproduction and milk yield of Black Bengal goats (Capra hircus)
}

\author{
S. Sultana, M. J. Khan, M. R. Hassan ${ }^{1^{*}}$ and M. A. M. Y. Khondoker ${ }^{2}$
}

Department of Animal Nutrition, Bangladesh Agricultural University, Mymensingh-2202, Bangladesh

\begin{abstract}
Sixteen female Black Bengal goats $(10 \pm 0.6$ months of age and $11.5 \pm 1.3 \mathrm{~kg}$ live weight) were divided into four groups having four goats in each. In a completely randomized design, A, B, C and D were given 150, 200, 250 and $300 \mathrm{~g}$ concentrate mixture with ad libitum green grasses. Total dry matter (DM) intake (333.6, 374.7, 416.3 and $456.5 \mathrm{~g} /$ day in groups $\mathrm{A}, \mathrm{B}, \mathrm{C}$ and $\mathrm{D}$, respectively) was significantly $(\mathrm{P}<0.01)$ influenced by the level of concentrate in the diet. Crude protein (CP) intake (45.2, 57.0, 66.4 and $75.7 \mathrm{~g} /$ day) was significantly $(\mathrm{P}<0.01)$ higher in group $\mathrm{D}$ and lower in group A. Daily weight gain of kids did not differ significantly between groups. Feed and protein conversion efficiency was not significantly influenced by the concentrate level in the diet. Milk yield was significantly $(\mathrm{P}<0.01)$ increased $(206.8,233.4,359.3$ and $374.7 \mathrm{~mL} /$ day for groups $\mathrm{A}, \mathrm{B}, \mathrm{C}$ and $\mathrm{D}$, respectively) with the supplementation of concentrate. It is suggested to supplement $250 \mathrm{~g}$ of concentrate daily to female goats in addition to ad libitum roughage. (Bangl. vet. 2012. Vol. 29, No. 1, 7 - 16)
\end{abstract}

\section{Introduction}

Bangladesh has 20.6 million goats, representing $58.8 \%$ of the livestock population, of which $>90 \%$ comprise Black Bengal goats. According to BBS (2001) landless and small farmers keep $52.4 \%$ of the goats and medium and large farmers keep the rest. The Black Bengal goat is renowned for its high prolificacy, quality skin and tasty meat (Husain et al., 1998). The breed is early-maturing with first kidding occurring at about 12 months of age. Does kid twice a year or thrice in two years. Goats are efficient users of grasses, shrubs and tree leaves, and by-products of human foods, but this cannot satisfy their requirements. The productivity of goats may be increased by concentrate feeding (Madibela and Segwagwe, 2008) or supplying good quality forage (Muri and Jordao, 1991). The importance of concentrate supplementation on growth and productivity of goats is well recognized (Kochapakdee et al., 1994). Live weight of dams affects the weight gain of the kids, more obviously during the second and third month after birth (Romagesa Vila, 1981).

\footnotetext{
1 Bangladesh Livestock Research Institute, Savar, Dhaka, Bangladesh

2 Department of Animal Breeding and Genetics, Faculty of Animal Husbandry, Bangladesh

Agricultural University, Mymensingh-2202, Bangladesh

*Corresponding author:- E-mail: mdrakibulhassan@gmail.com
} 
Although, the Black Bengal is a dwarf goat, at 12 months of age live weight gain was $15 \mathrm{~kg}$ (Husain et al., 1998). The present study was undertaken to evaluate common grasses available for feeding and the effect of concentrate supplementation on voluntary feed intake, and productive and reproductive performance.

\section{Materials and Methods}

Sixteen female goats of live weight $11.5 \pm 1.3 \mathrm{~kg}$ at $10 \pm 0.56$ months of age were used for a 240-day feeding trial. Goats were assigned to four dietary treatments in a completely randomized design with four goats in each treatment. All animals received ad libitum green grass as the basal diet. They received concentrate mixture 150, 200, 250 and 300g/day per goat for group A, B, C and D, respectively: $100 \mathrm{~kg}$ of concentrate mixture contained $30 \mathrm{~kg}$ crushed maize, $50 \mathrm{~kg}$ wheat bran, $19 \mathrm{~kg}$ mustard oil cake, $0.1 \mathrm{~kg}$ vitamin mineral premix and $1 \mathrm{~kg}$ salt. Concentrate mixture contained $15.7 \mathrm{~g}$ crude protein $(\mathrm{CP})$ and 13.2 megajoule (MJ) of metabolisable energy (ME)/ $\mathrm{kg}$ dry matter (DM). All goats were housed in a tin shed having wooden slatted floor raised above the ground with sufficient space to keep them comfortable. Goats were allowed free movement in a paddock daily from 8 to $10 \mathrm{AM}$. Before grazing, all the animals were supplied with $50 \%$ of the concentrate mixture and the remaining $50 \%$ was supplied at $4 \mathrm{PM}$. After grazing, the animals were supplied chopped green grass ad libitum. The feed was offered individually in plastic pans and fresh drinking water was available at all times. Kids were kept with their mother for the whole study period and no additional feed was provided to the kids. Feed samples were mixed and sub-samples were dried in the sun. After drying, grasses were ground. Crushed maize, mustard oil cake and wheat bran were purchased from the local market, and representative samples were collected at the time of their procurement for proximate analysis following the methods of AOAC (1980).

The weight of goats was recorded every 30 days in the morning. The birth weight $(\mathrm{kg})$ of kids was taken by digital weighing balance within one hour after birth and fortnightly. Kids were separated from their does overnight (8 PM - 6 AM). In the morning, kids were weighed by weighing balance and allowed to suck. After sucking, kids were weighed again and milk production was calculated.

Data on reproductive performance including number of services per pregnancy, gestation length, litter size, birth weight of kids, postpartum doe weight and placenta weight were recorded. Data were compiled, tabulated and analysed using Statistical Package for Social Sciences (SPSS 11.5). Least significant difference (LSD) test were performed for comparison with SPSS (version 11.5).

\section{Results and Discussion}

\section{Composition of feed}

The chemical composition of grasses and concentrates is shown in Table 1 . Daulat (1988) observed wheat bran and mustard oil cake contained 88.0 and 90.7\% 
DM; and 12.0 and 31.2\% CP, similar to the present findings. Misbah (2007) found that wheat bran contained $87.5 \% \mathrm{DM}$ and $13.8 \% \mathrm{CP}$. Napier, German and roadside grass contained 24.3, 23.9 and 21.1\% DM; and 8.7, 8.3 and 9.2\% CP. On the other hand, Mahfuz (2004) found that German grass contained $15.9 \%$ and $8.5 \%$ of DM and CP, respectively. Alam (1990) observed $19.7 \%$ and $8-10 \%$ of DM and CP in roadside grasses, similar to the present findings.

Table 1. Chemical composition (g/100g DM) of grasses and concentrates

\begin{tabular}{l|c|c|c|c|c|c|c}
\hline \multirow{2}{*}{ Feed items } & \multirow{2}{*}{$\mathrm{DM}$} & \multicolumn{7}{c}{$\mathrm{g} / 100 \mathrm{~g}$ DM (mean $\pm \mathrm{sd})$} \\
\cline { 3 - 8 } & & $\mathrm{OM}$ & $\mathrm{CP}$ & $\mathrm{CF}$ & $\mathrm{EE}$ & $\mathrm{NFE}$ & Ash \\
\hline Maize crushed & $90.9 \pm 1.5$ & $96.6 \pm 1.3$ & $8.9 \pm 1.0$ & $2.4 \pm 0.4$ & $4.7 \pm 1.9$ & $80.6 \pm 4.5$ & $3.4 \pm 1.3$ \\
Mustard oil cake & $92.5 \pm 3.3$ & $90.1 \pm 1.1$ & $33.0 \pm 3.1$ & $11.8 \pm 0.3$ & $11.4 \pm 2.8$ & $33.9 \pm 4.7$ & $9.9 \pm 1.1$ \\
Wheat bran & $87.6 \pm 1.8$ & $94.1 \pm 0.4$ & $16.4 \pm 0.9$ & $10.2 \pm 2.0$ & $3.3 \pm 0.5$ & $64.3 \pm 2.8$ & $5.9 \pm 0.4$ \\
Conc. mix & $89.6 \pm 1.7$ & $93.6 \pm 1.0$ & $15.7 \pm 1.7$ & $11.6 \pm 0.9$ & $6.5 \pm 1.5$ & $59.9 \pm 3.9$ & $6.4 \pm 0.7$ \\
Napier grass & $24.3 \pm 5.5$ & $90.3 \pm 2.8$ & $8.7 \pm 1.8$ & $29.2 \pm 4.0$ & $2.7 \pm 0.7$ & $50.3 \pm 18.1$ & $9.7 \pm 2.8$ \\
German grass & $23.9 \pm 6.7$ & $90.0 \pm 2.9$ & $8.3 \pm 1.0$ & $33.7 \pm 0.6$ & $2.1 \pm 0.2$ & $45.9 \pm 22.9$ & $10.1 \pm 3.0$ \\
Roadside grass & $21.1 \pm 4.0$ & $90.3 \pm 1.4$ & $10.9 \pm 1.6$ & $21.4 \pm 0.8$ & $2.0 \pm 0.2$ & $55.9 \pm 10.3$ & $9.7 \pm 1.4$ \\
\hline
\end{tabular}

Effects of concentrate supplementation on intake and growth

The effect of concentrate supplementation on intake and growth of goats is shown in Table 2.

\section{Dry matter (DM) intake}

Feeding goats concentrate as supplement significantly $(\mathrm{P}<0.01)$ increased intake of DM expressed as total voluntary intake (333.6, 374.7, 416.3 and $456.5 \mathrm{~g} /$ day), percentage of live weight $(2.7,2.9,3.0,3.5 \%)$ and percentage of metabolic body size $(54.1,57.3,61.7,71.8 \mathrm{~g} /$ day) in groups A, B, C and D, respectively. Dry matter intake from grasses decreased with the increasing level of supplementation of concentrate, but the differences between groups were not significant $(\mathrm{P}>0.05)$. Dry matter intake from concentrate was significantly $(\mathrm{P}<0.01)$ higher in group $\mathrm{D}$ than in group A. Devendra and McLeory (1983) observed that DM intake in meat-type goats hardly exceeded 3\% of live weight. Ranjhan (1980) reported that DM intake in goats varied from 1.5 to $3.7 \%$ of live weight. Kabir et al. (2002a) mentioned that DM intake of goat was $3.5 \%$ of live weight. The present finding on DM intake corresponds well with the above observations.

\section{Crude protein $(\mathrm{CP})$ intake}

Total CP intake $(\mathrm{kg})$ and daily $\mathrm{CP}$ intake was significantly higher in D than in A. Kabir et al. (2002a) observed CP intake of $76.1 \mathrm{~g} /$ day in goats supplemented with $250 \mathrm{~g}$ concentrate per day, slightly higher than the present findings. Similarly, Salim et al. 
(2002) observed that CP intake of supplemented group was higher $(63.7 \mathrm{~g} /$ day) than that of the control group $(26.5 \mathrm{~g} /$ day).

Table 2. Effects of concentrate supplementation on growth performance of Black Bengal does

\begin{tabular}{|c|c|c|c|c|c|c|}
\hline \multirow[t]{2}{*}{ Parameters } & \multicolumn{4}{|c|}{ Groups } & \multirow[t]{2}{*}{ SEM } & \multirow{2}{*}{$\begin{array}{l}\text { Level of } \\
\text { sig. }\end{array}$} \\
\hline & A & B & $\mathrm{C}$ & $\mathrm{D}$ & & \\
\hline Initial live weight (kg) & 11.4 & 11.5 & 11.5 & 11.6 & 0.6 & NS \\
\hline Final live weight (kg) & 15.5 & 16.8 & 18.0 & 18.2 & 0.8 & NS \\
\hline Average live weight gain (g/day) & 27.6 & 35.1 & 43.2 & 43.8 & 6.5 & NS \\
\hline Total live weight gain $(\mathrm{kg})$ & 4.1 & 5.3 & 6.5 & 6.6 & 0.5 & NS \\
\hline DM intake from grass (g/day) & 203.2 & 201.0 & 197.4 & 194.5 & 19.0 & NS \\
\hline DM intake from concentrate (g/day) & $131.5^{\mathrm{a}}$ & $173.7^{b}$ & $218.9^{c}$ & $262.0^{\mathrm{d}}$ & 7.1 & $* *$ \\
\hline Total CP intake (kg) & $6.8^{\mathrm{a}}$ & $8.5^{\mathrm{b}}$ & $10.0^{c}$ & $11.4^{\mathrm{d}}$ & 2.2 & $* *$ \\
\hline Total DM intake (g/day) & $333.6^{\mathrm{a}}$ & $374.7 \mathrm{~b}$ & $416.3^{c}$ & $456.5^{\mathrm{d}}$ & 19.5 & $* *$ \\
\hline Total DM intake (kg) & $50.2^{\mathrm{a}}$ & $56.5^{\mathrm{b}}$ & $62.4^{c}$ & $68.4^{\mathrm{d}}$ & 2.2 & $* *$ \\
\hline DM intake (\% live weight) & $2.7^{\mathrm{a}}$ & $2.9^{a}$ & $3.0^{\mathrm{a}}$ & $3.5^{b}$ & 0.3 & $* *$ \\
\hline DM intake (g/kg0.75/day) & $54.1^{\mathrm{a}}$ & $57.3^{\mathrm{a}}$ & $61.7^{\mathrm{a}}$ & $71.8^{\mathrm{b}}$ & 4.4 & ** \\
\hline Crude protein intake (g/day) & $45.2^{\mathrm{a}}$ & $57.0^{\mathrm{b}}$ & $66.4^{\mathrm{c}}$ & $75.7^{\mathrm{d}}$ & 2.0 & $* *$ \\
\hline $\begin{array}{l}\text { Feed conversion efficiency } \\
\text { (DMI/LWG) }\end{array}$ & 12.1 & 10.7 & 9.6 & 10.4 & 0.6 & NS \\
\hline $\begin{array}{l}\text { Protein conversion efficiency } \\
\text { (CPI/DMI) }\end{array}$ & 1.6 & 1.6 & 1.5 & 1.7 & 0.4 & NS \\
\hline
\end{tabular}

NS-Not significant; ${ }^{* *} \mathrm{P}>0.01$

abcdData having dissimilar superscripts differ significantly $(\mathrm{P}<0.01)$

Weight gain of dam

The average daily growth rate of dams is shown in Table 2. In the present result, the growth rate did not differ significantly between groups; it increased with the level of concentrate supplementation. Kochapakdee et al. (1994) reported that female growing goats receiving concentrate diet $(0.8 \% \mathrm{BW})$ gained $36 \mathrm{~g} /$ day, while goats on control diet (grazing only) gained $14 \mathrm{~g} /$ day, which partially agrees with the present findings. Kabir et al. (2002b) found that the growth rate of Black Bengal goats ranged from 37.5 to $40.3 \mathrm{~g} /$ day and mentioned that high level of protein in the diet significantly $(\mathrm{P}<0.05)$ influenced the live weight gain. Supplementation of concentrate increased growth rate (Sikosana and Maphosa, 1995), which corresponds to the present results. 
Feed and protein conversion efficiency (PCE)

In the present trial, feed conversion efficiency (FCE) was not influenced by the level of concentrate (Table 2). Hossain et al. (2003) in his experiment with $250 \mathrm{~g}$ concentrate supplementation observed FCR of 10.8, which corresponds well with the group B and D. Similar FCR value was observed by Rahman et al. (1991).

Protein conversion efficiency (PCE) in the present study did not differ significantly between groups. Hossain et al. (2003) found higher efficiency of utilization of protein $[\mathrm{CP} / \mathrm{g}$ live weight gain (LWG)] with increased dietary energy supplementation.

\section{Reproductive performance}

Reproductive traits of does fed different levels of concentrate supplementation are presented in Table 3.

\section{Number of services per pregnancy}

The numbers of services per pregnancy in group A, B, C and D are presented in Table 3 and did not differ significantly between groups. Hossain et al. (2004) reported that Black Bengal goats required 1.2 - 1.4 services per pregnancy. Chowdhury et al. (2002) found 1.7 services per pregnancy in Bengal goats fed high levels of concentrate, and 1.2 in goats fed low levels. Similarly, Alam (1992) found 1.4 services per pregnancy in Black Bengal goats under farming conditions.

\section{Litter size}

Litter size did not differ significantly between groups (Table 3). Litter size of Black Bengal goats varies from one to four (Hassan et al., 2007). Hossain et al. (2004) stated that parity had great influence on litter size: in the $1^{\text {st }}, 2^{\text {nd }}$ and $3^{\text {rd }}$ parity and it was 1.1, 1.8 and 2.0, respectively. On the other hand, Moulick et al. (1996) reported an average litter size of 2.1 in Black Bengal goats.

Table 3. Effects of concentrate supplementation on reproductive performance of Black Bengal goats

\begin{tabular}{|c|c|c|c|c|c|}
\hline \multirow[t]{2}{*}{ Parameters } & \multicolumn{4}{|c|}{ Groups } & \multirow{2}{*}{$\begin{array}{l}\text { Level of } \\
\text { sig. }\end{array}$} \\
\hline & A & $\mathrm{B}$ & $\mathrm{C}$ & $\mathrm{D}$ & \\
\hline Number of service per pregnancy & $2.8 \pm 0.4$ & $2.2 \pm 0.3$ & $1.8 \pm 0.3$ & $1.7 \pm 0.2$ & NS \\
\hline Gestation length (day) & $151.6 \pm 8.4$ & $150.1 \pm 7.2$ & $149.2 \pm 6.1$ & $149.3 \pm 7.1$ & NS \\
\hline Litter size [number (no.) & $1.6 \pm 0.1$ & $1.7 \pm 0.3$ & $1.9 \pm 0.1$ & $1.9 \pm 0.2$ & NS \\
\hline Birth weight of kids (kg) & $1.0 \pm 0.1$ & $1.0 \pm 0.2$ & $1.3 \pm 0.0$ & $1.3 \pm 0.1$ & NS \\
\hline Post-partum weight of does (kg) & $13.2 \pm 0.7$ & $14.5 \pm 0.8$ & $15.0 \pm 0.9$ & $14.8 \pm 0.4$ & NS \\
\hline Placental weight $(\mathrm{g})$ & $175.0 \pm 12.3$ & $187.5 \pm 15.6$ & $230.0 \pm 11.5$ & $197.5 \pm 13.7$ & NS \\
\hline
\end{tabular}

NS-Non-significant 


\section{Birth weight of kids}

Average birth weights of kids did not differ significantly between groups (Table 3). Dam body weight and sex of the kid are influence by the birth weight of kids. Male kids are heavier than females (Hafez, 1962).

\section{Post-partum doe weight and placental weight}

Level of concentrate did not significantly affect the post-partum weights of does or placenta weight (Table 3). Mellado et al. (2005) suggested that higher post-partum weight indicates the higher birth weight of kids. On the other hand, placenta weight is mainly influenced by the litter size (Hafez, 1962).

\section{Growth performance of kids}

The growth rates of kids fed different levels of concentrates are presented in Table 4, with no significant differences among groups. Kabir et al. (2002b) found higher daily growth rate $(62.4 \mathrm{~g} /$ day) in kids that received the high protein diet $(16 \%$ $\mathrm{CP})$ than those fed the low protein diet $(10 \% \mathrm{CP} ; 45.4 \mathrm{~g} /$ day) and the effect continued up to weaning. Tiwari et al. (1983) suggested that better growth rate could be achieved by maintaining kids in smaller groups and under better feeding and management conditions. Growth rate is also influenced by the litter size (Husain et al., 1998).

Table 4 . Fortnightly growth rate of Black Bengal kids

\begin{tabular}{l|c|c|c|c|c}
\hline \multirow{2}{*}{ Days } & \multicolumn{4}{|c|}{ Groups } & \multirow{2}{*}{ Level of sig. } \\
\cline { 2 - 5 } & $\mathrm{A}$ & $\mathrm{B}$ & $\mathrm{C}$ & $\mathrm{D}$ & \\
\hline $0-15$ & $33.3 \pm 6.2$ & $43.3 \pm 6.3$ & $34.2 \pm 9.3$ & $33.3 \pm 5.7$ & NS \\
\hline $16-30$ & $36.7 \pm 7.5$ & $40.0 \pm 7.2$ & $48.3 \pm 6.9$ & $46.7 \pm 7.1$ & NS \\
$31-45$ & $36.7 \pm 5.1$ & $36.7 \pm 8.3$ & $40.3 \pm 11.4$ & $36.7 \pm 5.2$ & NS \\
$46-60$ & $37.3 \pm 9.3$ & $36.3 \pm 8.1$ & $38.3 \pm 8.6$ & $37.7 \pm 6.3$ & NS \\
$61-75$ & $50.7 \pm 7.7$ & $45.0 \pm 6.7$ & $42.3 \pm 4.9$ & $56.0 \pm 13.4$ & NS \\
$76-90$ & $46.7 \pm 12.3$ & $40.3 \pm 15.6$ & $44.3 \pm 11.5$ & $51.3 \pm 13.7$ & NS \\
Average & $40.2 \pm 12.9$ & $40.3 \pm 12.5$ & $41.3 \pm 12.4$ & $43.6 \pm 15.6$ & NS \\
\hline
\end{tabular}

NS-Non-significant

Sadullah (1991) reported daily gains of $41.0 \mathrm{~g} /$ day from birth to six months of age. Bhuiyan et al. (1996) suggested that higher level of concentrate supplementation increased daily live weight gain of kids. Similarly, Sharma and Ogra (1990) stated that supplementation of concentrate feed significantly $(\mathrm{P}<0.05)$ improved total DM intake, growth rate and FCR of kids. Paul et al. (1990) found that goats given a supplementation of concentrates were heavier from 4 to 6 months of age than goats that were only allowed to browse $(13.8 \mathrm{vs} 8.0 \mathrm{~kg}$; $\mathrm{P}<0.01)$. 


\section{Milk Yield}

Milk yield of Black Bengal does increased significantly $(\mathrm{P}<0.01)$ with the increased level of concentrate supplementation (Table 5). Average milk yields were $206.8,233.4,359.3$ and $374.7 \mathrm{~g} /$ day for groups A, B, C and D, respectively. Chowdhury et al. (2002) found that the average milk yield of Black Bengal does was 334g/day when fed 200-300g concentrates per day: the NRC (1981) recommendation is $556 \mathrm{~g} /$ day.

Table 5. Milk yield of Black Bengal does

\begin{tabular}{l|ccc|c|c}
\hline \multirow{2}{*}{ Months } & \multicolumn{4}{|c|}{ Milk yield (g/day) } & \multirow{2}{*}{ Level of sig. } \\
\cline { 2 - 5 } & Group A & Group B & Group C & Group D & \\
\hline $1^{\text {st }}$ & $222.0^{\mathrm{a}} \pm 12.2$ & $271.0^{\mathrm{a}} \pm 19.4$ & $390.5^{\mathrm{b}} \pm 16.1$ & $413.0^{\mathrm{b}} \pm 28.2$ & $* *$ \\
$2^{\text {nd }}$ & $219.5^{\mathrm{a}} \pm 26.2$ & $240.8^{\mathrm{a}} \pm 13.8$ & $367.8^{\mathrm{b}} \pm 27.4$ & $395.5^{\mathrm{b}} \pm 29.2$ & $*$ \\
$3^{\text {rd }}$ & $179.0^{\mathrm{a}} \pm 17.2$ & $188.5^{\mathrm{a}} \pm 23.4$ & $319.5^{\mathrm{b}} \pm 21.7$ & $315.5^{\mathrm{b}} \pm 31.8$ & $*$ \\
\hline Average & $206.8^{\mathrm{a}} \pm 18.5$ & $233.4^{\mathrm{a}} \pm 18.9$ & $359.3^{\mathrm{b}} \pm 21.8$ & $374.7^{\mathrm{b}} \pm 29.7$ & $*$ \\
\hline
\end{tabular}

${ }^{* * P}<0.01$

In lactating goat, Kawas et al. (1991) found that milk production was not significantly affected by the forage-to-concentrate ratio $(75: 25,60: 40$ and $45: 55)$ but tended to increase with an increase in concentrate feeding: this might be due to energy being diverted into body fat by infusion of propionic acid, whereas acetic acid infusion shifts energy output to milk production. Reverdin and Sauvant (1991) suggested that milk composition and yield are influenced by type of forage but not by type of concentrate.

\section{Conclusions}

Concentrate supplementation increased feed intake of does, live weight gain of kids in the first month and milk yield of does, but the positive effect was not correlated with the level of supplementation. Daily supplementation of $250 \mathrm{~g}$ concentrate to suckling goats in addition to ad libitum roughage feeding could be recommended.

\section{References}

Alam MR 1990: Effects of Feeding Grasses and Supplements and Drenches on Growth of Goats. In the Development of Feeding Strategies for Improving Ruminant Productivity in Areas of Fluctuating Nutrient Supply Through the Use of Nuclear and Related Techniques. FAO/IAEA Research Coordination Meeting, Khon Kaen, Thiland, October 22-26.

Alam MR 1992: Research on Goat production System in Bangladesh. Proceeding of International Conference on Recent Advances in Goat Production held in New Delhi, India. 
AOAC 1980: Official Methods of Analysis (13 th edn). Association of Official Analytical Chemists, Washington DC, USA.

BBS 2001: Bangladesh Census of Agriculture, Bangladesh Bureau of Statistics, Dhaka, Bangladesh.

Bhuiyan R, Baruah KK, Das PC 1996: Growth Response and Carcass Characteristics of Crossbred Kids Fed Ration Having Different Concentrate to Roughage Rations. Indian Journal of Animal Nutrition 13 167-169.

Chowdhury SA, Bhuiyan MSA, Faruk S 2002: Rearing Black Bengal goat under semiintensive management. 1. Physiological and reproductive performances. AsianAustralasian Journal of Animal Science 15 477-484.

Daulat H 1988: The effect of using different calorie protein ratio on the performance of RIR growing chicken. MS Thesis, Department of Poultry Science, Faculty of Animal Husbandry, Bangladesh Agricultural University, Mymensingh, Bangladesh.

Devendra C, Mcleory GB 1983: Goat and Sheep Production in the Tropics. Longman group, Longman house, Burnt Mill, Harlow, Essex, UK.

Hafez EJH 1962: Reproduction in Farm Animals. 5th Edition., Lea and Febiger, Philadelphia, USA pp: 410-412.

Hassan MM, Mahmud SMN, Islam SKMA, Miazi OF 2007: A comparative study on reproductive performance and productivity of the Black Bengal and crossbred goats at Atrai, Bangladesh. University Journal of Zoology, Rajshahi University 26 55-57.

Hossain SMJ, Sultana N, Alam MR, Hasnath MR 2004: Reproductive and productive performance of black Bengal goat under semi intensive management. Journal of Biological Science 4 537-541.

Hossain ME, Shahjalal M, Khan MJ, Bhuiyan AA 2003: Effect of Dietary Energy Supplementation on Feed Intake, Growth and Reproductive Performance of Sheep under Grazing Condition. Pakistan Journal of Nutrition 2 148-152.

Husain SS, Amin MR, Islam ABMM 1998: Goat production and its Breeding Strategy in Bangladesh. Proceeding of first national workshop on Animal Breeding, Bangladesh Agricultural University, Mymensingh, Bangladesh.

Kabir F, Shahjalal M, Miah G, Uddin MJ, Rahman MZ 2002a: Effect of concentrate supplementation to grazing on growth and reproductive performance in female goat and sheep. Journal of Biological Sciences 2 333-335.

Kabir F, Sahjalal M, Chowdhury SA, Alam J, Islam MR 2002b: Effect of protein supplementation to grazing on growth and reproductive performance in female goats and sheep. Pakistan Journal of Biological Science 5 719-721.

Kawas JR, Lopes S, Danelon DL, Lu CD 1991: Influence of forage-to-concentraterations on intake, digestibility, chewing and milk production of dairy goats. Small Ruminant Research 4 11-18. 
Kochapakdee S, Pralomkam W, Saithanoo S, Lowpetchara A, Norton BW 1994: Productivity of female goats grazing newly established pasture with varying levels of supplementary feeding. Asian-Australasian Journal of Animal Science 7 289-293.

Mahfuz P 2004: Effect of different doses of nitrogen and phosphorus fertilizer on yield, chemical composition and nutritive value of German grass. MS Thesis, Department of Animal Nutrition, Faculty of Animal Husbandry, Bangladesh Agricultural University, Mymensingh, Bangladesh.

Madibela OR, Segwagwe BVE 2008: Nutritional effects of supplementary feeding on maternal blood metabolites, cortisol, thyroid hormones levels and on outcome of pregnancy of dry season kidding Tswana goats. Livestock Research and Rural Development 204.

Mellado M, Mellado J, García JE, López R 2005: Lifetime reproductive performance of goats as a function of growth traits and reproductive performance early in life. Journal of Applied Animal Research 27 113-116.

Misbah UA 2007: Study on the productive and reproductive performance of Black Bengal goat under improved management and feeding "pusti". MS Thesis, Department of Animal Nutrition, Faculty of Animal Husbandry, Bangladesh Agricultural University, Mymensingh, Bangladesh.

Moulick SK, Guha H, Gupta S, Mitra DK, Bhattacharya S 1996: Factors affecting multiple birth in Black Bengal Goats. Indian Journal of Veterinary Science and Animal Husbandry 36 154-163.

Muri J, Jordao C 1991: Preliminary data on growth of goats raised in an improved pasture system in Mozambique. In: Proceeding of the third international symposium on the nutrition of herbivores. The Malaysian Society of Animal Production, pp. 65-71.

Paul S, Sahu BB, Singh D, Rawat PS 1990: Effect of season of birth, weaning age and concentrate supplementation on growth and chevon production. Indian Journal of Animal Production and Management 6 182-186.

Rahman MM, Islam MR, Rahman MM, Zaman MA 1991: Study on the livestock feeds and fodder and feeding practices in Bangladesh and their nutritive evaluation. $3^{\text {rd }}$ Annual Progress Report, Bangladesh Livestock Research Institute, Savar, Dhaka, Bangladesh.

Ranjhan SK 1980: Animal Nutrition in the Tropics. Vikas publishing house Pvt. Ltd. Vikas house, Ghajiabod, UP, India, pp. 163-167.

Reverdin CS, Sauvant D 1991: Evaluation and utilization of concentrates in goats. In Goat Nutrition. Wageningen, Netherlands; Pudoc, pp. 172-183.

Romagesa Vila JA 1981: Breeds. In: Gall C editors. Goat Production. London: Academic Press, pp. 73-78.

Sadullah M 1991: Availability and utilization of feed resources for ruminant production in Bangladesh. Paper Presented on Training Courses on Feed Information System, Bangladesh Agricultural Research Council, Dhaka, Bangladesh. 
Salim HM, Shahjalal M, Tareque AMM, Kabir F 2002: Effects of concentrate supplementation on growth and reproductive performance of female sheep and goat under grazing condition. Pakistan Journal of Nutrition 1 191-193.

Sharma K, Ogra JL 1990: Growth Rate and Feed Conversion Efficiency of Barbari Kids Fed Khejri (Prospis cineria) Leaves with Different Level of Concentrate. Indian Veterinary Journal 67 252-254.

Sikosana JLN, Maphosa V 1995: Growth and Carcass Characteristics of young Indigenous (Matabele) Castrated Goat Grazing Acasia Thornveld, and Offered Supplementary Feed during the Dry Season. Journal of the Zimbabwe Society for Animal Production 7 199-202.

Tiwari SB, Saini AL, Bhat PN 1983: Management of Barbari goats. Annual Report, Central Institute for Research on Goats, Makhdoom, Mathura, India, pp. 72-75. 